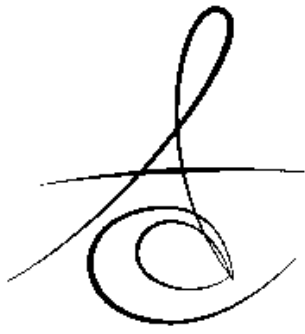

Makale Kodu/Article code: 1898

Makale Gönderilme tarihi: 16.10 .2014

Kabul Tarihi: 28.11.2014

\section{LARGE COMPLEX ODONTOMA IN MANDIBLE: A CASE REPORT ${ }^{\not}$}

MANDİBULADA BÜYÜK KOMPLEKS ODONTOMA: VAKA RAPORU ${ }^{\star}$

Yrd. Doç. Dr. Adnan KILINÇ*

Arş. Gör. Dt. Nesrin SARUHAN*

Prof. Dr. Ümit ERTAŞ

Arş. Gör. Dt. Tahsin TEPECİK*

\author{
Prof. Dr. Nesrin GÜRSAN**
}

\section{ABSTRACT}

Purpose: Odontomas are benign odontogenic tumors of the jaws and constitutes about $22 \%$ of all odontogenic tumors. Odontomas are divided into two subtypes, complex odontoma and compound odontoma, with differences in their macroscopic and microscopic features. Compound odontomas are encountered mostly in the anterior maxilla, whereas complex odontomas are often seen in the posterior mandible. The aim of this case report was to present surgical removal of a complex odontoma associated with second and third molar and inferior alveolar nerve.

Material Method: 21 year-old-male patient was referred our department with a large complex odontoma which is seated in the left mandibular molar region and associated with impacted third and second molar and inferior alveolar nerve. Impacted teeth and complex odontoma was removed surgically.

Results: There was no complication or numbness postoperatively.

Conclusion: Complex odontomas are benign odontogenic tumors and recurrence is unusual.

Keywords: Odontogenic tumor, treatment

\section{INTRODUCTION}

Odontogenic tumors are extremely rare $(0.002 \%$ to $0.1 \%$ ) and odontomas constitutes $21 \%$ to $67 \%$ of all odontogenic tumors. So odontomas are the most common odontogenic tumors. In most cases, odontomas are diagnosed in 1 or 2 decades of life. ${ }^{1,2}$ Odontomas are considered to be developmental
ÖZET

Amaç: Odontomalar, tüm odontojenik tümörlerin ortalama \%22'sini oluşturan çenelerin benign odontojenik tümörleridir. Odontomalar mikroskopik ve makroskopik özelliklerine göre kompleks ve kompound olmak üzere iki gruba ayrilırlar. Kompound odontomalar genellikle anterior maksillada görülmesine rağmen kompleks odontomalar genellikle posterior mandibulada görülürler. Bu vaka raporunun amacl, ikinci ve üçüncü molar ve inferior alveolar sinirle ilişkili kompleks odontomanın cerrahi olarak çıkartılmasını sunmaktır.

Gereç ve Yöntem: Mandibular molar bölgede gömülü ikinci ve üçüncü molar dişle ve inferior alveolar sinirle ilişkili büyük kompleks odontoma bulunan 21 yaşında erkek hasta kliniğimize başvurdu. Gömülü dişler ve kompleks odontoma cerrahi olarak çıkartıldı.

Bulgular: Postoperatif olarak herhangi bir komplikasyonla veya uyuşuklukla karşılaşılmadı.

Sonuç: Kompleks odontomalar benign odontojenik tümörlerdir ve genellikle nüks görülmez.

Anahtar Kelimeler: Odontojenik tümör, tedavi

anomalies (hamartomas), rather than true neoplasms. Odontomas are divided into compound and complex types. The compound odontoma is composed of multiple, small toothlike structures. The complex odontoma consists of a conglomerate mass of enamel and dentin, which bears no anatomic resemblance to a tooth. ${ }^{3}$ Although compound and complex odontomas may be found in any site, the compound type is more often seen in the anterior maxilla; complex odontomas

${ }^{*}$ Ataturk University, Faculty of Dentistry, Department of Oral and Maxillofacial Surgery

${ }^{* *}$ Ataturk University, Medical Faculty, Department of Pathology

${ }^{\ddagger}$ This case report was presented as a poster 20th International Congress of Turkish

Association of Oral and Maxillofacial Surgeons, 19-23 May 2013, Antalya, Turkey. 
occur more often in the molar regions of either jaw. ${ }^{3,4}$ Clinical signs suggestive of an odontoma include a retained deciduous tooth, an impacted tooth, and alveolar swelling. These lesions generally produce no symptoms. ${ }^{5}$ Odontomas should be removed by conservative surgery because they have very low growth potential and enucleation or surgical excision is curative. Recurrence is unusual. ${ }^{4}$ Here we present a case of a complex odontoma with a fused impacted third and second molars and also associated with the nervus alveolaris inferior.

\section{CASE REPORT}

A 21 year-old-male patient visited our department for routine examination. Mandibular left second and third molars were missing. Dental/maxillofacial trauma or infections were not reported. The patient did not described any surgical procedure in the past. Panoramic radiograph was taken and the odontoma like structure was found accidentally on the left mandibular molar region (Fig. 1). The lesion was seemed fused to impacted molars and dominated on the place of the mandibular second molar. The boundaries of the lesion had an appearance of interfering the mandibular canal. The whole molar region was asymptomatic, and the patient did not describe any complaint about the site. There has also been no history of numbness of the area innervated by nervus alveolaris inferior.

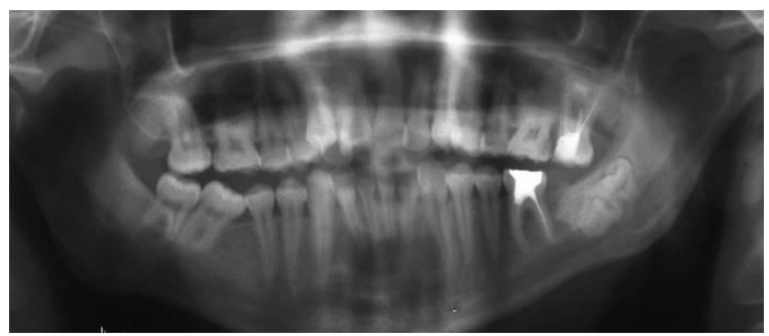

Figure 1. Orthopantomograph revealing radioopaque lesion in the left mandibular angle region involving the impacted molars.

Computerised Tomography (CT) was performed in order to analyze the boundaries of the lesion and its proximity to the mandibular canal (Fig. 2). CT measurements revealed close association to upper cortical border of the canal.

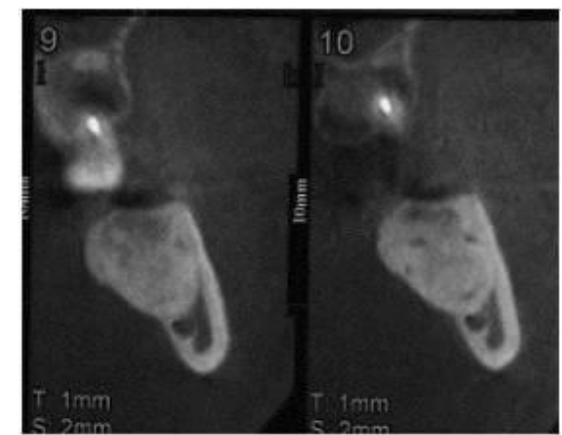

Figure 2. Cross-section CT scan showing nervus alveolaris inferior and the extent of the lesion buccolingually.

Under local anesthesia surgical removal of odontoma and impacted teeth were decided. A vestibular approach was used to access the site. The cortical bone was removed with a metal burr and the amorphous mass was prepared.

Impacted molars were detached from the toothlike process. The tumor and the impacted molars were taken out (Fig. 3). Specimens were sent for histopathologic examination. On macroscopical examination there were twelve biopsy which had a gray/white color, measured $0.8 \mathrm{~cm}$ in diameter. Microscopically, pathological specimen shows multiple toothlike structures (Fig. 4).

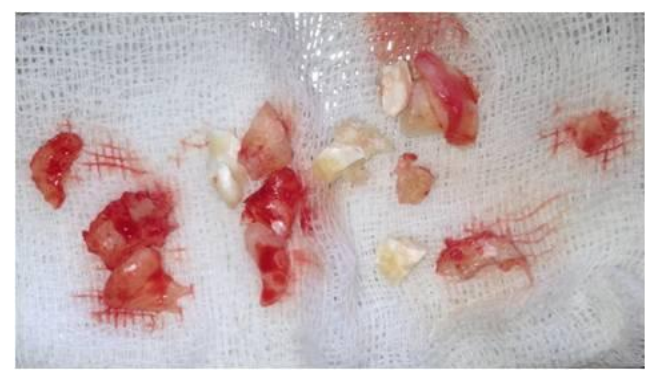

Figure 3. Excised specimen

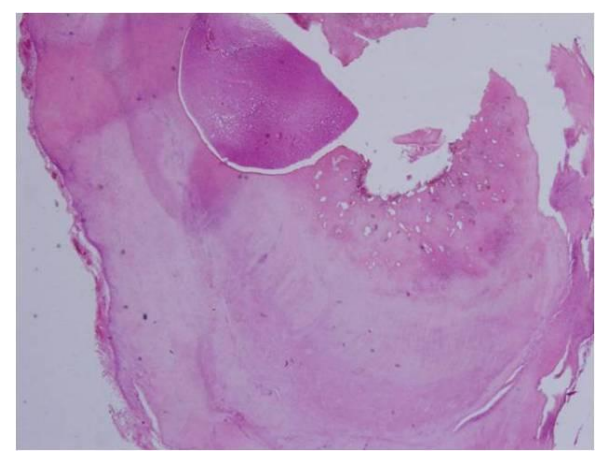

Figure 4. Toothlike structure (X40, H\&E) 
After surgical removal of tumor, inferior alveolar nerve was seen at the lingual side. The surgery was concluded with a primary flap closure. Numbness was not seen postoperatively. 1 year follow up bone healing was uneventful (Figure 5).

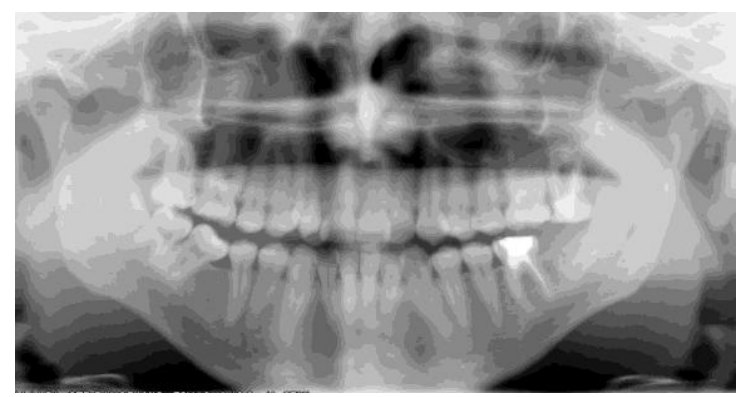

Figure 5. Postoperative healing was seen (1 year follow up).

\section{DISCUSSION}

Odontomas are classified as benign mixed odontogenic tumors in the World Health Organization classification, but are thought to be developmental anomalies rather than benign neoplasms. ${ }^{4}$ The pathogenesis is not clear, but trauma during primary dentition, heredity, and genetic mutations are accepted possible etiologic factors. ${ }^{6}$ They are a common cause of symptomless tooth impaction. ${ }^{1}$ There is currently no consistent evidence that odontomas have a predilection for a specific gender. Some studies emphasise the female predilection ${ }^{7}$, on the contrary, some of them connect their results with odontoma tendency to occur more in men. ${ }^{6}$ There are also studies pointing out that there is no predilection for gender. ${ }^{8,9}$ In this case report, pathogenesis wasn't clear and patient didn't have any trauma history. Patient without any symptoms was complaining missing teeth at the posterior mandibular region.

Histologically, 2 main types of odontomas are recognized: complex and compound. Compound odontomas consist of many separate, small, toothlike structures and usually form in the anterior part of the jaws and may give rise to a painless swelling. Compound ones are seen mostly in younger patients. ${ }^{8}$ Complex odontomas tend to appear in the posterior part of the jaws and consist of a disorganized mass of hard and soft dental tissues with no morphologic resemblance to a tooth. ${ }^{10}$ In this case report complex odontoma was seen in the posterior part of mandible.

All the structures that compose the tooth can be found on the odontomas; these are enamel, dentin, cementum and pulpal tissue. ${ }^{11}$ In the compound type these structures are built up like a normal tooth (e.g. the pulp and the dentin are in the center, cementum and the enamel are on the outer surface of the odontoma), while in the complex type, as the name implies, they are seen in irregular form. ${ }^{12}$ In our case tooth like structures were found in irregular form.

Odontomas might be very small and remain in their position without getting noticed for years. They are associated with permanent or primary tooth eruption problems. ${ }^{8}$ Some of them, although rare, might be seen in erupted position. ${ }^{13-16}$ Patient had a eruption problem of permanent second mandibular molar in our case.

Different factors are thought to be involved in the eruption process since odontomas lack periodontal membrane; which is a necessity for normal tooth eruption. Increasing in size of the odontomas may be one of the mechanisms and it may lead to bone remodeling and resorption of the overlying bone. ${ }^{17}$ Clinically, 3 types of odontomas are recognized in the literature: intraosseous, extraosseous (soft tissue), and erupted. ${ }^{18}$ In this case report, intraosseous complex odontoma was presented.

The radiologic manifestation of odontoma is unique even on conventional radiographs (ie, periapical or panoramic radiographs), appearing as a hyperdense, noncystic, well-defined mass with a radiolucent margin. Because of the small size, favorable location, and distinct appearance of the average odontoma, more extensive radiologic methods, such as cross-sectional tomography, conebeam CT, and CT, are not indicated on a regular basis and should be left for extraordinarily large and obscure cases. ${ }^{1}$ Ameloblastic odontoma and ameloblastic fibroodontoma are seen in radiographs with similar features. Therefore all cases of odontoma should be sent to the histologic examination for accurate diagnosis. ${ }^{6}$

In this case, we performed CT to analyze the degree of the relationship of the complex odontoma to inferior alveolar nerve. Panoramic radiography did not provided sufficient information for treatment planning. Although resection under the protection of the impacted tooth is the suggested treatment of choice in one study, ${ }^{1}$ we extracted the impacted third molar owing to associating of the inferior alveolar nerve canal and the tooth was fused with the lesion. 


\section{CONCLUSION}

Odontomas are common, but complex odontomas are rare than compound odontomas. Complex odontomas should be surgically excised because they are characterized by expansion of cortical plates and if left untreated can cause pathological fracture of the bone.

\section{REFERENCES}

1. Troeltzsch M, Liedtke J, Troeltzsch V, Frankenberger $R$, Steiner $T$. Odontoma-associated tooth impaction: accurate diagnosis with simple methods? Case report and literature review. Journal of oral and maxillofacial surgery : official journal of the American Association of Oral and Maxillofacial Surgeons 2012;70:e516-20.

2. Ertaş Ü, Yavuz MS. Kompound odontoma (Bir vaka raporu). Atatürk Üniversitesi Diş Hekimliği Fakültesi Dergisi 2003;13;99-101.

3. Neville BW, Damm DD, Allen CM, Bouquot JE. Odontogenic cysts and tumors. Oral and Maxillofacial Pathology, Noida, Saunders. Elsevier Publications 2009;3:683-7.

4. Soluk Tekkesin M, Pehlivan S, Olgac V, Aksakallı N, Alatlı C. Clinical and histopathological investigation of odontomas: review of the literature and presentation of 160 cases. Journal of Oral and Maxillofacial Surgery 2012;70:1358-61.

5. Regezi JA, Sciubba JJ, Jordan RC. Oral pathology: clinical pathologic correlations: Elsevier Health Sciences; 2012;11;289.

6. Iatrou I, Vardas E, Theologie-Lygidakis N, Leventis M. A retrospective analysis of the characteristics, treatment and follow-up of 26 odontomas in Greek children. Journal of oral science 2010;52:439-47.

7. Garcia-Consuegra L, Junquera LM, Albertos JM, Rodriguez. Odontomas. A clinical-histological and retrospective epidemiological study of 46 cases. Med Oral 2000;5:367-72.

8. An $\mathrm{SY}$, An $\mathrm{CH}$, Choi KS. Odontoma: a retrospective study of 73 cases. Imaging Sci Dent 2012;42:7781.

9. Serra-Serra G, Berini-Aytes L, Gay-Escoda C. Erupted odontomas: a report of three cases and review of the literature. Med Oral Patol Oral Cir Bucal 2009;14:299-303.
10. Cawson RA, Odell EW. Cawson's essentials of oral pathology and oral medicine: Elsevier Health Sciences; 2008, $8^{\text {th }}$ ed, 152.

11. Curreri RC, Messer EJ, Abramson AL. Complex odontoma of the maxillary sinus: report of case. J Oral Surg 1975;33:45-8.

12. Slootweg PJ. An analysis of the interrelationship of the mixed odontogenic tumors--ameloblastic fibroma, ameloblastic fibro-odontoma, and the odontomas. Oral Surg Oral Med Oral Pathol 1981;51:266-76.

13. Rumel A, de Freitas A, Birman EG, Tannous LA, Chacon PT, Borkas S.. Erupted complex odontoma. Report of a case. Dentomaxillofac Radiol 1980;9:5-9.

14. Ohtawa Y, Ichinohe S, Kimura E, Hashimoto S. Erupted complex odontoma delayed eruption of permanent molar. Bull Tokyo Dent Coll 2013;54:251-7.

15. Gomel M, Seckin T. An erupted odontoma: case report. J Oral Maxillofac Surg 1989;47:999-1000.

16. Tozoglu S, Yildirim U, Buyukkurt MC. An erupted complex odontoma. N Y State Dent J 2010;76:523.

17. Vengal M, Arora H, Ghosh S, Pai KM. Large erupting complex odontoma: a case report. J Can Dent Assoc 2007;73:169-73.

18. Junquera $L$, de Vicente JC, Roig $P$, Olay $S$, Rodriguez-Recio $O$. Intraosseous odontoma erupted into the oral cavity: an unusual pathology. Medicina oral, patologia oral y cirugia bucal 2005;10:248-51.

\author{
Yazışma Adresi \\ Dt. Nesrin SARUHAN \\ Atatürk Üniversitesi, Diş Hekimliği Fakültesi, \\ Ağız, Diş ve Çene Cerrahisi A D. Erzurum \\ Fax: 0904422360945 \\ TIf: 0904422311747 \\ e-mail: dt_nesrin@yahoo.com
}

